\title{
Complaint Intentions of Consumers of Pakistan Restaurant Industry
}

\author{
Kamran Mukhtiar, Nafees Asmat, Muhammad Arshad, Muhammad Aftab Ali, \\ Hammad Ali Lodhi, Ather Waqas \\ MS Scholars (Department of Management Sciences) \\ The Islamia University of Bahawalpur, Pakistan. \\ arshad_gopang@yahoo.com \\ DOI:10.5296/ ijld.v3i6.6211 URL: http://dx.doi.org/10.5296/ ijld.v3i6.6211
}

\begin{abstract}
Purpose - The purpose of this paper is to predict which factors can determine consumer's intentions to complain when they meet service failure in restaurant industry.

Design/methodology/approach - quantitative data was collected through the instrument of a survey questionnaire. Data were collected from 250 consumers to assess the Influence of attitude, subjective norm, and Self-efficacy on the intention to complain.

Findings - The results show that the attitudes toward complaining and self-efficacy have significant effects on the consumer complaint intention. Also, self-efficacy of complaining is analyzed as the antecedents.
\end{abstract}

Practical implications - the results shows that in order to intensify the consumers attitude toward complaining in hospitality industry, service provider should encourage complaints to locate the failure and make policies to make the consumer satisfied/loyal. Here in the restaurant industry, when consumers (having high degree of self-efficacy) face faulty services, they focus on better solution in reaction to service failure by better using their expertise, skills and resources.

Originality/value - In this study it has be proven that perceived attitudes toward complaint and self-efficacy are very important determinants which directly affects Consumer's intention to make complains. This study also explores the effect of self-efficacy on consumer complaints behavior and provides a more holistic view of the determinants which affect customer`s complaint behavior.

Keywords: Complaint intentions, restaurant industry, customer satisfaction 


\section{Introduction}

Hotel restaurant managers concern a lot about customer satisfaction to survive and for growth purpose in the industry. From the revenue point of view, customer satisfaction is very important for hotels (Barlow, 1996). Higher level of customer satisfaction comes from meeting the expectations of customers. But the problem is that it is very difficult to know about the expectations of customers unless they provide feedback to hotels management. Feedback can be in different forms in different situations, but feedback in the form of complaints is very productive and beneficial source to make customer's satisfied (Sanes, 1993).

Hence, customer's complaint behavior (CCB) is the focal point for academic researchers (e.g. Rogers et al., 1992). Bad consequences can be faced due to lack of knowledge of CCB and also due to poor handling of customer's complaints. Jeopardizing of company can be happen due to spreading bad messages about the company by the dissatisfied customers (Lewis, 1983).

To cope with bad situations and to enhance customer satisfaction and loyalty, implementation of an effective complaint management system is necessary (Kemp, 1999). That system should productively and positively response to customers individual actions. An action by individual to communicate negative message about a product or service is called complaint behavior (Jacoby and Jaccard, 1981). Complaints can be direct to the service provider (the manufacturer or the distributor), or to the third parties (consumer protection bodies and media) that are not directly involved in the transaction (Singh and Pandya, 1991; Davidow and Dacin, 1997). Complaints to supplier by dissatisfied customers, demand solution of their dissatisfaction in the form of an economic or material reward, a suggestion for improvements or even, emotional relief (Nyer, 2000). Consumers who didn't got any solution from the product/service provider or who see a problem as more severe, complaints to third party (Hogarth et al., 2001).

One of the functions of dissatisfaction is the customer complaint behavior (Williams et al., 1993). Singh and Wilkes (1996) also elaborated that dissatisfaction is one of the important attributes to complaints. Morganosky and Buckley (1986) told another reason that education is one of the important attribute of complainers. Publicly complaining people are younger in age, having better education and higher income (Day and Landon, 1977).

If service failures handled appropriately at the early stage, they lead to positive response from customers (Bitner et al., 1990). Service providers should have a system to know the causes of complaints and to encourage the complainers for improving their products and services by complaining (East, 2000). Loyalty and commitment should be the purpose when fulfilling the desires and satisfying the customers (Zeithaml and Bitner, 2000). In some of the cases dissatisfied customers do not complaint about service providers, because they are hesitated to complain (Blodgett et al., 1995). That is why attitude toward complaining (ATC) is the main characteristic of the consumers complain behavior because, most of the time consumer intention to complain, get influence from ATC (Singh, 1989). 


\section{$\Lambda$ Macrothink}

Certainty of success and not feeling hesitation to complain make more positive attitude of the consumers toward complaining (Richins, 1982). In remarkable situation like service failure, theory elaborates a pertinent behavior-attitude affiliation (Fishbein and Ajzen, 1975; Ajzen and Fishbein, 1980). Halstead and Dro" ge (1991) express that attitude related to action of complaining are concerned to the other steps of the complaining process. It means attitude toward complaining can influence consumer concepts due to steps of organizations improvement strategies in response to complaints. These strategies can occur during or after the complaints process. Generally individual perceived risk, confidence, attitude \& propensity to make complain and complaints channel choices are importantly related to attitude towards complaining (Halstead and Dro“ ge, 1991; Huppertz and Mower, 2003; Oh, 2006; Richins, 1982; Singh, 1989).

Attitudes are reflected by beliefs, norms are reflected by normative belief and self-efficacy is reflected by the control over resources \& opportunities which are needed for the existence of a behavior (Ajzen, 1991). Ajzen, (1991) describe the self-efficacy same as the behavioral control which was described by the Bandura (1997). We will use self-efficacy as the variable in our study. If two individuals are willing to perform a same intention to conduct a behavior, the person with more self-efficacy will be handling the situation in a much better way (Ajzen, 1991). Due to the general nature of the theory of planned behavior (TPB) does not specify the beliefs which are associated with the specific behavior. So these beliefs are still to be explored by the further researchers.

\section{Literature review}

Theory of reasoned action states that favorable attitude and subjective norms certainly lead to intentions (Fishbein and Ajzen, 1975; Ajzen and Fishbein, 1980; Fishbein, 1980). These intentions comprises of personal and social influence (Ajzen and Fishbein, 1980). The attitudinal component shows attitude of an individual toward an act or behavior and the subjective importance of the behavior or act is reflected by normative component. These two determinants show the different characteristics in different situations, means behavior and individual preferences predict the intention to take an action. Subjective norms comprise of cognitive elements that are based on significant judgmental expectations of others. Attitude, amiability and inimitability of an act are less cognitive and more effective than the subjective norm (Bagozzi et al., 1992). Attitude towards behavior depicts the belief about engaging in the behavior and relevant assessment of the belief (Fishbein and Ajzen, 1975).

Ajzen (1985) provided a new variable, named (perceived behavioral contro)l in theory of reasoned action to measure behaviors and behavioral intentions. Fishbein and Cappella (2006) used self-efficacy as perceived behavior control in their research model. Ajzen (2002) also measured perceived behavior control with the help of self-efficacy. The performers require essential resources and opportunities to conduct a behavior, when they don't have volitional control. Ajzen $(1985,1991)$ argue that theory of planned behavior (TPB) depicts both attitude toward a behavior and subjective norm which reflect the intention to execute a behavior. Complaints in the hospitality industry require two way communications with service provider. 


\section{Intention to complain}

The TRA and TPB do not explain how intention converts into behavior or why people do not act according to their intentions (Bagozziet al., 1992). According to the Ajzen (1991) that intention is the motivation of a person to execute a behavior and time or effort he/she is willing to take specific action. Intention of taking a particular action is an internal motivation. Kim et al., 2003 extended the definition of Ajzen that the complain intention is the intention of disgruntled customer to make complaints to the firm. Here in our research model of study, complain intention is dependent on the three variable, 1.attitude toward complaining, 2.subjective norm, 3.Perceived self-efficacy.

\section{Attitude toward complaining}

An action most importantly includes an attitude that pursue or not to pursue a behavior (Ajzen, 2005). The theory of reasoned behavior concludes that intention of person includes two fundamental determinants, his/her nature as well as influence (Ajzen and Fishbein, 1980). And also according to this theory that positive and negative evaluation of nature of a particular performed behavior is called personal factor evaluation (Ajzen and Fishbein, 1980). Singh (1989) stressed that normative consideration (should I complain or not) and social benefits (It should benefit others) should be taken as benchmark to test the appropriateness of the complaining behavior. Richins (1982) explains that individual's personal norms toward complaining, personal benefit of complaining and societal benefits of complaining are the basics of attitudes toward complaining. Bodey and Grace (2006) express that consumers have positive attitudes toward complaining if they perceive greater possibility of success of their complaints and due to this confidence; they complain most of the time.

To have a more precise point of view, it can be said that customers having negative attitude towards complaining is dependent on personal reasons which abolish the loyalty of consumer toward the company or organization. Likewise, if social benefits are the source of concern, then there are also remarkable chances that they will be no more loyal to the company or organization (Erdogan and Norman, 2010; Rizwan et al., 2013).

H1: Attitude toward complain have significant effect on intention to complain in restaurant industry.

\section{Subjective norms}

Subjective norms are the norms which are set by individuals and groups to create perceived expectations to act upon. The referent opinion motivates the individuals to create intention to comply the expectations of that referent group (Fishbein and Ajzen, 1975). Mathieson,(1991) and Taylor and Todd, (1995) elaborated that subjective norms attached with the influence of superior's, peers, family and friends, have close links with intention of complain. So subjective norms are the combination of individual perception and motivation assessments toward all referent groups.

.H2: Subjective norm have significant effect on intention to complain in restaurants industry. 


\section{Macrothink}

\section{Self-efficacy}

It is an individual belief to utilize his expertise and skills to achieve specific goals and to perform under the given conditions. More the self-efficacy will be, more will be the control over behaviors, environment, thoughts, feelings and actions. According to Bandura, (1997) the individual having high self-efficacy can better utilize or integrate the resources and expertise to make optimal, effectual coping strategies to encounter environmental challenges. The higher self-efficacy helps individuals to moderate their aggressive behavior and to act strategically to find out what they want (Bandur etal., 2003; Mikolajczak et al. 2006; Rizwan et al., 2013). The person who scores highly on emotional intelligence manifests greater degree of self-efficacy (Mikolajczak and Luminet, 2008). The concept of behavior control is very much relevant to the Banduras concept of self-efficacy. Perceived behavioral control is the belief of a person that how easily or difficultly a specific behavior can be performed (Ajzen, 1988). Also self-efficacy is a person ability that how well he/she handles a specific situation. Fishbein and Cappella (2006) used self-efficacy as perceived behavior control in their research model; Ajzen (2002) also measured perceived behavior control with the help of self-efficacy and use it as an item. Here in the restaurant industry several sophisticated techniques can be used to record customer complaints and to cope with service failures.

H3: Self-efficacy has significant effect on intention to complain in restaurant industry.

\section{Theoretical model:}

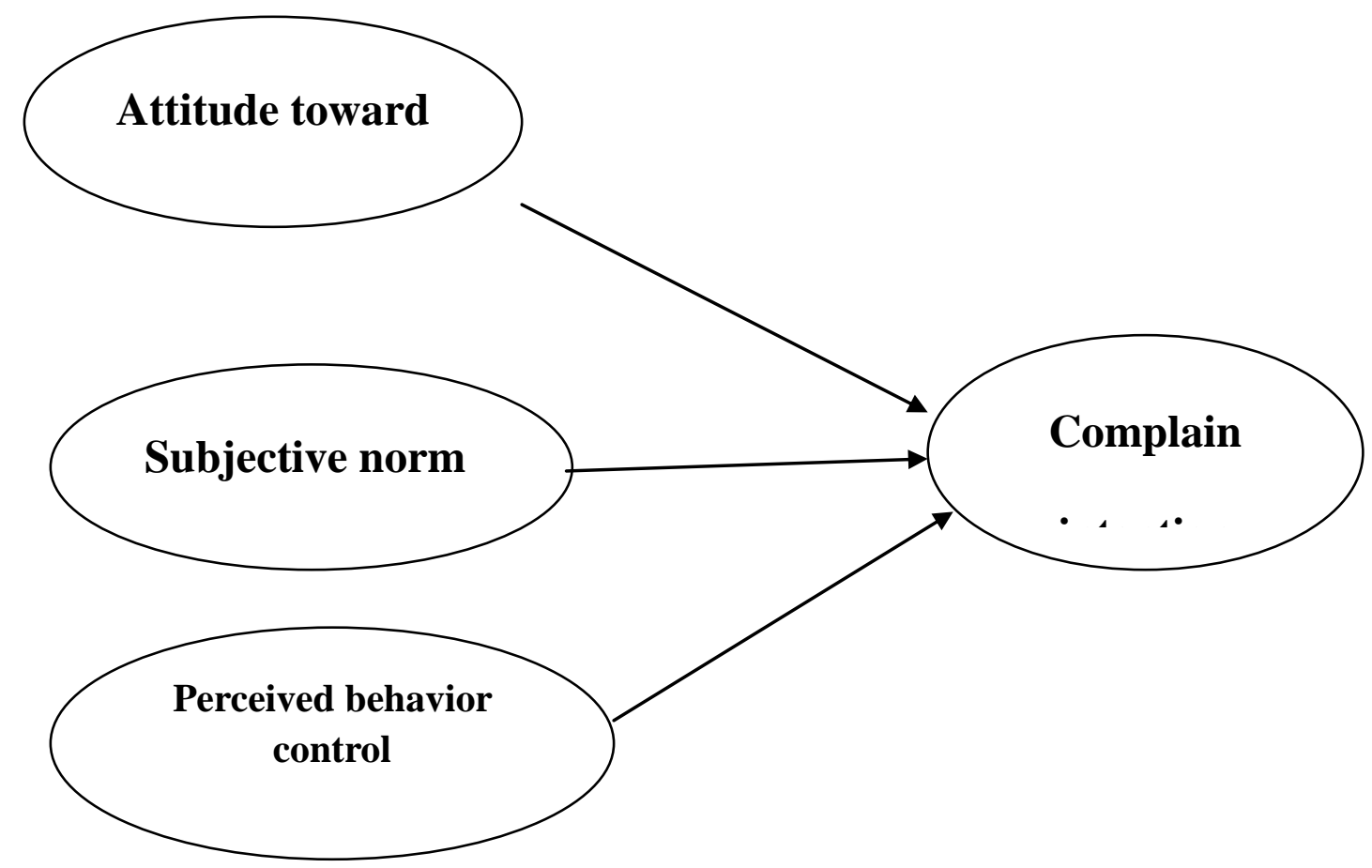




\section{Research methodology}

\section{Sample/Data}

In order to collect data to understand situation about complain intention of consumer towards restaurant, a sample of 230 respondents were asked to participate in a self-administered questionnaire. The population for the current research is restaurant visitors in Pakistan. Non-probability sampling technique that is convenience sampling was used in this study. Two main qualifications were necessary to participate in the self-administered survey. First, sample members should be the consumer of restaurants. Secondly, they must have enough knowledge about the restaurant services. We selected the sample members from the Bahawalpur city of Pakistan. The sample data was collected from the two main clusters, university students and working professionals.

\section{Instruments and Measures}

Questionnaire of the current study have two main purposes: first is to analyze the relationships of different variables in complain intention of consumer in restaurant industry. Secondly, to collect information about the different characteristics of the respondents that can be used to understand the variation in the different categories. Questionnaire of the current study is divided into two sections; Section 1 contains personal and demographic variables. This section collects the respondent's information about Gender, age, income, education and status. Section 2 includes the latent variables that are important in the current study. These variables include attitude toward complaining, subjective norm, self-efficacy and complain intention. This section of study is depending upon the past literature and already used questionnaires. (Table 1) The scales of the current study were adopted from previous literature and published studies. The first variable of the study, attitude toward complaining is having four items and scale has been taken from Blodget etal. (1993); Singh, (1989). Subjective norm variable is having two items and scales was taken from Taylor and Todd (1995a). Self-efficacy variable is having five items and scale was taken from Schwarzer and Jerusalen's (1995). The net variable is complaining intention having three items was taken from Day etal. (1991); Singh, (1989). 


\section{$\Lambda$ Macrothink}

Table 1: Scale of Study

\begin{tabular}{|c|c|c|c|}
\hline No. & Variable & Items & Reference \\
\hline 1 & $\begin{array}{l}\text { Attitude toward } \\
\text { Complaining }\end{array}$ & $\begin{array}{l}\text { 1. I feel uncomfortable if not complain directly about } \\
\text { dissatisfactory product or service to the service provider } \\
\text { 2. I feel obliged to complain directly about dissatisfactory } \\
\text { product or service to the service provider } \\
\text { 3. People should complain that much for it happens } \\
\text { 4. It is necessary to ask for change or return if the failing product } \\
\text { or service does not cost much }\end{array}$ & $\begin{array}{l}\text { Blodgett et al. } \\
(1993), \quad \text { Singh's } \\
(1989)\end{array}$ \\
\hline 2 & Subjective Norm & $\begin{array}{l}\text { 1. People who influence my behavior would think that I should } \\
\text { complain } \\
\text { 2. People who are important to me would think that I should } \\
\text { complain }\end{array}$ & $\begin{array}{l}\text { Taylor and Todd } \\
\text { (1995a) }\end{array}$ \\
\hline 3 & Self-efficacy & $\begin{array}{l}\text { 1. I am confident that I could deal efficiently with } \\
\text { unexpected service episodes } \\
\text { 2. Thanks to my resourcefulness, I know how to handle } \\
\text { unforeseen service incidents } \\
\text { 3. If someone opposes me in a service incident, I can find the } \\
\text { means and ways to get what I want } \\
\text { 4. When I am confronted with a service failure, I can usually find } \\
\text { several solutions } \\
\text { 5. I can always manage to deal with service failures if I try hard } \\
\text { enough }\end{array}$ & $\begin{array}{l}\text { Schwarzer and } \\
\text { Jerusalem's } \\
\text { (1995) }\end{array}$ \\
\hline 4 & $\begin{array}{l}\text { Complain } \\
\text { Intention }\end{array}$ & $\begin{array}{l}\text { 1. I will forget the unsatisfactory experience and not complaint } \\
\text { any more } \\
\text { 2. I will complain to employee or manager right after } \\
\text { experiencing dissatisfaction } \\
\text { 3. I will make the service provider take proper action right after }\end{array}$ & $\begin{array}{l}\text { Day et al., 1981; } \\
\text { Singh, } 1989\end{array}$ \\
\hline
\end{tabular}

understood it easily to response productively. A total of 230 questionnaires were selected included from 250 questionnaires and remaining are not include in further analysis due to incomplete invalid responses. 61.1percent respondent were male and remaining were of opposite gender; age of 64.8 percent respondents was between 20-25 because of greater percentage of youngsters in Pakistan`s population, while only 0.9percent of respondent were over the age of 40; 43.5 percent respondents hold a four-year bachelor degree; 34.8 percent hold post-graduate degree and 0.4 percent respondents were PHDs'; 55.2percent are having the income level between 10,000-15,000 PKR monthly. After completing the collection of filled questionnaire, these questionnaires were coded and entered into SPSS sheet for future analysis. 


\section{Reliability Analysis}

Overall Cronbach's alpha of complain intention questionnaire items is 0.748 , that is more acceptable and recommended value 0.50 by Nunnally (1970). This shows that all the 14 items were reliable to measure the opinions of consumer toward complaining intention.

Table 2: Reliability of Measurement Instrument

\begin{tabular}{|l|l|l|}
\hline Scales & Items & Cronbach Alpha \\
\hline Attitude toward Complaining & 4 & 0.552 \\
\hline Subjective Norm & 2 & 0.623 \\
\hline Self-efficacy & 5 & 0.567 \\
\hline Complain Intention & 3 & 0.529 \\
\hline
\end{tabular}

Results and Analysis

Profile of the respondent

Personal and demographic information, such as Gender, Age, Income, Education level and status are presented in the following table.

Table 3: Profile of Respondent

\begin{tabular}{|c|c|c|c|}
\hline & Category & Frequency & Percentage \\
\hline \multicolumn{4}{|l|}{ Variable } \\
\hline Gender & $\begin{array}{l}\text { Male } \\
\text { Female }\end{array}$ & $\begin{array}{l}151 \\
71\end{array}$ & $\begin{array}{l}61.1 \\
30.9\end{array}$ \\
\hline Age & $\begin{array}{l}15-20 \\
20-25 \\
25-30 \\
30-35 \\
35-40 \\
\text { Above40 }\end{array}$ & $\begin{array}{l}65 \\
149 \\
11 \\
2 \\
1 \\
2\end{array}$ & $\begin{array}{l}28.3 \\
64.8 \\
4.8 \\
0.9 \\
0.4 \\
0.9\end{array}$ \\
\hline Income & Below 15000 & 127 & 55.2 \\
\hline
\end{tabular}




\begin{tabular}{|c|c|c|c|}
\hline & $\begin{array}{c}15000-25000 \\
25000-35000 \\
35000-45000 \\
45000-55000 \\
\text { Above } 55000\end{array}$ & $\begin{array}{l}44 \\
19 \\
19 \\
3 \\
18\end{array}$ & $\begin{array}{l}19.1 \\
8.3 \\
8.3 \\
1.3 \\
7.8\end{array}$ \\
\hline Education & $\begin{array}{l}\text { Matriculation } \\
\text { Inter } \\
\text { Bachelor } \\
\text { Master } \\
\text { Ms/Mphil } \\
\text { PHD }\end{array}$ & $\begin{array}{l}2 \\
14 \\
100 \\
80 \\
33 \\
1\end{array}$ & $\begin{array}{l}0.9 \\
6.1 \\
43.5 \\
34.8 \\
14.3 \\
0.4\end{array}$ \\
\hline Status & $\begin{array}{l}\text { Student } \\
\text { Employed } \\
\text { Businessman } \\
\text { Unemployed } \\
\text { Housewife }\end{array}$ & $\begin{array}{l}164 \\
52 \\
12 \\
- \\
2\end{array}$ & $\begin{array}{l}71.3 \\
22.6 \\
5.2 \\
- \\
0.9\end{array}$ \\
\hline
\end{tabular}

\section{Hypothesis Testing}

According to the results of the study, Attitude toward complaining has significant effect on the intention to complain in restaurant industry. Specifically Attitude toward complaining have significant positive relationship with $(\beta=0.179)$ and $(\mathrm{p}<0.009)$. That means attitude towards complaining contribute more than $17 \%$ to complain intention and that validates the H1. While considering the significance between subjective norm and complain intention, the results of the current study shows no Significant relationship between these two variables with $(\beta=0.103)$ and $(p<0.120)$. We reject the $\boldsymbol{H} 2$ and conclude that the subjective norm have no significant effect on complain intention. The regression results of the study confirm the significant positive relationship between self efficacy and complain intention with $(\beta=0.28)$ and $(p<0.000)$. According to these results, self-efficacy contributes more than $28 \%$ to complain intention. These results validate $\mathbf{H 1}$ and H3. (Table 4) 


\section{Macrothink \\ International Journal of Learning \& Development \\ ISSN 2164-4063 2013, Vol. 3, No. 6}

Table 4: Regression Results

\begin{tabular}{|c|c|c|c|c|c|c|c|}
\hline Hypothesis & \multicolumn{2}{|c|}{ Model Variable } & Estimate & S.E & C.R & $\mathbf{P}$ & Results \\
\hline $\mathrm{H} 1$ & ATTC & CI & 0.214 & 0.082 & 0.179 & $* * *$ & Supported \\
\hline $\mathrm{H} 2$ & $\mathrm{SN}$ & $\mathrm{CI}$ & 0.083 & 0.053 & 0.103 & 1.20 & $\begin{array}{l}\text { Not } \\
\text { supported }\end{array}$ \\
\hline $\mathrm{H} 3$ & $\mathrm{SE}$ & CI & 0.340 & 0.078 & 0.285 & $* * *$ & Supported \\
\hline
\end{tabular}

Research model Results:

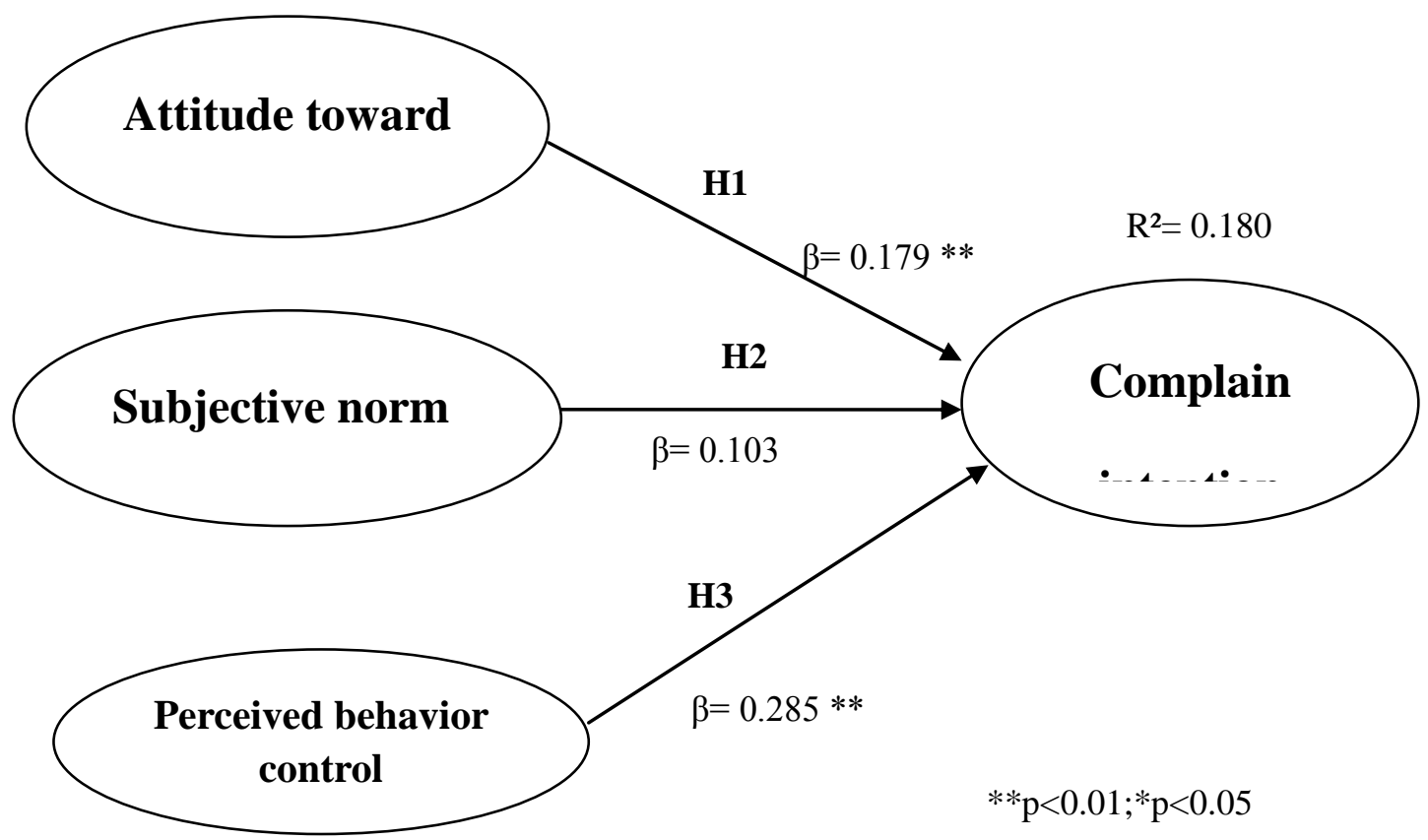




\section{Discussion and Managerial Implication}

In this study it has been proven that attitude toward complain and self-efficacy directly affects the intention of consumers to make complains whereas subjective norm have no significant effect on the intention of consumer to make complains. Self-efficacy helps consumer to make strategies to cope with the service failure in moderate way. When services failure occur in the restaurant industry, consumers having high degree of self-efficacy will focus on better solution to service failure by better using their expertise, skills and resources. Previous research also shows that in some situations referent group had no effect on intention of consumer to make complain. In this concerned matter, parents, friends, professors and students are having very week influence on the concerned consumers (George, 2004). And the consumers are depending just on their attitude to make complains. Battacherjee (2000) also did not find a strong relationship between subjective norms and intention, which can be due to external influences like mass media which is more persuasive. On the basis of these findings of this research companies should scrutinize its customer relationship management by keeping following recommendations in view. Firstly; service provider should make complain handling process by which service provider can check the process of delivery that where failures occur and try to settle these failures by providing some reward and compensation. Secondly; service provider should try to eliminate causes of failure from the process.

\section{Reference:}

Ajzen, I. and Fishbein, M. (1980), Understanding Attitudes and Predicting Social Behavior, Prentice-Hall, Englewood Cliffs, NJ.

Ajzen, I. (1985), "From intention to action: a theory of planned behavior", in Kuhl, J. and Beckmann, J. (Eds), Action Control: From Cognition to Behavior, Springer-Verlag, New York, NY, pp. 11-39.

Ajzen, I. (1988), Attitudes, Personality, and Behavior, Dorsey Press, Chicago, IL.

Ajzen, I. (1991),“The theory of planned behavior”, Organizational Behavior and Human Decision Processes, Vol. 50 No. 2, pp. 179-211.

Ajzen, I. (2002),"Perceived behavioral control, self-efficacy, locus of control, and the theory of planned behavior”, Journal of Applied Social Psychology, Vol. 32 No. 4, pp. 665-83.

Battacherjee, A. (2000), "Acceptance of e-commerce services: the case of electronic brokerages", IEEE Transactions on Systems, Man, and Cybernetics - Part A: Systems and Humans, Vol. 30 No. 4, pp. 411-20.

Blodgett, J.G., Wakefield, K.L. and Barnes, J.H. (1995), “The effects of customer service on consumer complaining behavior", Journal of Services Marketing, Vol. 9 No. 4, pp. 31-42.

Bagozzi, R.P., Baumgartner, H. and Yi, Y. (1992), "State versus action and the theory of reasoned action: an application to coupon usage", Journal of Consumer Research, Vol. 18 No. 4, pp. 505-18. 
Bitner, M.J. (1990), "Evaluating service encounters: the effects of physical surroundings and employee responses", Journal of Marketing, Vol. 54 No. 2, pp. 69-82.

Bandura, A. (1977), "Self-efficacy: toward a unified theory of behavioral change", Psychological Review, Vol. 84 No. 2, pp. 191-215.

Bandura, A., Caprara, G. V., Barbaranelli, C., Gerbino, M. and Pastorelli, C. (2003), " Role of Affective Self-Regulatory Efficacy in Diverse Spheres of Psychosocial Functioning", Child Development, Vol. 74 No 3, pp. 769-82.

Bearden, W.O. and Mason, J.B. (1984), "An investigation of influences on consumer complaint reports", in Kinnear, T.C. (Ed.), Advances in Consumer Research,Vol.11,Association for Consumer Research, Provo, UT, pp. 490-5.

Bitner, M.J.,Booms,B.H. and Tetreault, M.S. (1990), 'The service encounter: diagnosing favourable and unfavourable incidents' ', Journal of Marketing, Vol. 54, January, pp. 71-84.

Brumback, N. (1998), “'Inn style", Restaurant Business, Vol. 97 No. 3, pp. 47-59.

Bowen, J.T. and Morris, A.J. (1995), “'Menu design: can menus sell?", International Journal of Contemporary Hospitality Management, Vol. 7 No. 4, pp. 4-9.

Curry, L. (1995), “'Menu for change wins customers", People Management, Vol. 1 No. 22, November2, pp. 40-2.

Davidow, M. and Dacin, P.A. (1997), "Understanding and influencing consumer complaint behavior: improving organizational complaint management", Advances in Consumer Research, Vol. 24, pp. 450-6.

East, R. (2000), “Complaining as planned behavior”, Psychology \& Marketing,Vol. 17 No. 12, pp. 1077-95.

Fishbein, M.A. and Ajzen, I. (1975), Belief, Attitude, Intention and Behavior: An Introduction to Theory and Research, Addison-Wesley, Reading, MA.

Fishbein, M. (1980), “A theory of reasoned action: some applications and implications”, in Howe, H. and Page, M. (Eds), Nebraska Symposium on Motivation, University of Nebraska Press, Lincoln, NE, pp. 65-116.

Fishbein, M. and Cappella, J.N. (2006), "The role of theory in developing effective health communications", Journal of Communication, Vol. 56, S1, pp. S1-S17.

Grønhaug, K. and Zaltman, G. (1980), “Complainers and non-complainers revisited: another look at the data", in Monroe, K. (Ed.), Advances in Consumer Research, Association for Consumer Research, Washington, DC.

Hogarth, J.M., English, M. and Sharma, M. (2001), "Consumer complaints and third parties: determinants of consumer satisfaction with complaint resolution efforts", Journal of Consumer Satisfaction, Dissatisfaction and Complaining Behavior, Vol. 14, pp. 74-87. 


\section{Mll Macrothink}

International Journal of Learning \& Development

ISSN 2164-4063

2013, Vol. 3, No. 6

Halstead, D. and Droge, C. (1991), "Consumer attitudes toward complaining and the prediction of multiple complaint responses", Advances in Consumer Research, Vol.18, pp. 210-6.

Hoffman, K.D.,Kelley, S.W. and Rotalsky, H.M.(1995),"Tracking service failures and employee recovery efforts", Journal of Services Marketing, Vol. 2, pp. 49-61

Joey F. George, (2004),"The theory of planned behavior and Internet purchasing", Internet Research, Vol.14 Iss: 3 pp. 198 - 212

Jones, M.A., Reynolds, K.E., Mothersbaugh, D.L. and Beatty, S.E. (2007), “The positive and negative effects of switching costs on relational outcomes", Journal of Service Research, Vol. 9 No. 4, pp. 335-55.

Kim, C., Kim, S., Im, S. and Shin, C. (2003), "The effect of attitude and perception on consumer complaint intentions", Journal of Consumer Marketing, Vol. 20 Nos 4/5, pp. 352-71.

Kraft, F.B. (1977), "Characteristics of consumer complainers and complaint repatronage behavior", in Hunt, R.L.D.A.H.K. (Ed.), Consumer Satisfaction, Dissatisfaction and Complaining Behavior Proceedings, Indiana University, Bloomington, IN.

Lewis, R. (1981), "Restaurant advertising: appealsand consumers' intention”, Journal of Advertising Research, Vol. 21No. 5, pp. 20-7.

Mikolajczak, M. and Luminet, O. (2008), "Trait Emotional Intelligence and the Cognitive Appraisal of Stressful Events: An Exploratory Study ", Personality and Individual Differences, Vol. 44 No 7, pp. 1445-53.

Mikolajczak, M., Luminet, O. and Menil, C. (2006), "Predicting Resistance to Stress: Incremental Validity of Trait Emotional Intelligence over Alexithymia and Optimism", Psicothema, Vol. 18 No Suppl, pp. 79-88.

Mathieson, K. (1991), "Predicting user intentions: comparing the technology acceptance model with the theory of planned behavior", Information Systems Research, Vol. 2 No. 3, pp. 173-91.

Magnini, V.P. and Ford, J.B. (2004), "Service failure recovery in China", International Journal of Contemporary Hospitality Management, Vol. 16 No. 5, pp. 279-86.

Mason, J.B. and Himes, S.H.J. (1973), "An explanatory behavioral and socioeconomic profile of consumer action about dissatisfaction with selected household appliances", Journal of Consumer Affairs, Vol. 7, pp. 121-7.

Nyer, P. (2000), "An investigation into whether complaining can cause increased consumer satisfaction", Journal of Consumer Marketing, Vol. 17 No. 1, pp. 9-19.

Richins, M.L. (1982), “An investigation of consumers' attitudes toward complaining”, in Mitchell, A. (Ed.), Advances in Consumer Research, Vol. 9, Association for Consumer Research, Miami, FL, pp. 502-518. 
Reifner, U., Gorges, I. and Schmidtmann, I. (1980), "Ansatzpunkte fu" r eine selbsthilfeorientierte Verbraucherberatung: Ergebnisse einer empirischen Untersuchung", Journal of Consumer Policy, Vol. 4, pp. 212-30.

Rizwan, M., Ali, S. H., Akhter, S., Abbas, Y., Kanwal, A., Iqbal, S. \& Aziz, W. (2013) Determinants Affecting Consumer Complaining Behavior: A study in a University of Pakistan, Asian Journal of Empirical Research, 3(2), 160-174

Rizwan, M., Khan, A., Saeed, I., Shah, K., Azhar, N. \& Anam, W. (2013) Determinants of Customer Complaining Behavior, International Journal of Research in Computer Applications and Management, 3(3), 119-124

Smith, D.H. (1980), Participation in Social and Political Activities, Jossey-Bass, San Francisco, CA.

Singh, J. and Pandya, S. (1991), "Exploring the effects of consumers' dissatisfaction level on complaint behaviours", European Journal of Marketing, Vol. 25 No. 9, pp. 7-21.

Singh, A. (1989), "Review article: digital change detection techniques using remotely-sensed data”, International Journal of Remote Sensing, Vol. 10 No. 6, pp. 989-1003.

Singh, J. (1988), "Consumer complaint intentions and behavior: definitional and taxonomical issues”, Journal of Marketing, Vol. 52 No. 1, pp. 93-107.

Taylor, S. and Todd, P.A. (1995), "Understanding information technology usage: a test of competing models”, Information Systems Research, Vol. 6 No. 2, pp. 144-76.

Warland, R.H., Herrmann, R.O. and Moore, D.E. (1984), "Consumer complaining and community involvement: an exploration of their theoretical and empirical linkages", Journal of Consumer Affairs, Vol. 18, pp. 64-78.

Zeithaml, V.A. and Bitner, M.J. (2000), Services Marketing: Integrating Customer Focus across the Firm, McGraw-Hill, New York, NY.

Zeelenberg, M. and Pieters, R. (1999), "Comparing service delivery to what might have been: behavioral responses to egret and disappointment", Journal of Service Research, Vol. 2 No. 1, pp. 86-97 